\title{
Clinical picture of dermatitis herpetiformis
}

\section{Obraz kliniczny opryszczkowatego zapalenia skóry}

\author{
Joanna I. Rybak-d’Obyrn, Waldemar J. Placek \\ Department of Dermatology, University of Warmia and Mazury, Olsztyn, Poland \\ Katedra i Klinika Dermatologii, Uniwersytet Warmińsko-Mazurski, Olsztyn, Polska
}

Dermatol Rev/Przegl Dermatol 2019, 106, 615-624

DOI: https://doi.org/l 0.5 | |4/dr.2019.92734

\section{CORRESPONDING AUTHOR/ ADRES DO KORESPONDENCJI:} dr n. med. Joanna I. Rybak-d'Obyrn Katedra i Klinika Dermatologii Uniwersytet Warmińsko-Mazurski ul. Wojska Polskiego 30 10-229 Olsztyn, Polska e-mail: jrybakdobyrn@wp.pl

\begin{abstract}
Dermatitis herpetiformis is a rare, chronic, autoimmune blistering disease with hypersensitivity to gluten with the presence of intense pruritus. Symptoms of the disease are symmetrical, polymorphic skin lesions in a typical location. It is thought that dermatitis herpetiformis is a specific skin manifestation of celiac disease, with frequent asymptomatic gluten enteropathy. Both diseases are characterized by the same tissue compatibility antigens, the presence of circulating IgA antibodies against endomysium and transglutaminases, and clinical remission on a glutenfree diet. Non-adherence to this diet predisposes to the development of some tumours, autoimmune and thyroid gland diseases. The diagnosis of dermatitis herpetiformis is based on the findings of the characteristic IgA deposits in the skin papilla in the direct immunofluorescence test. Specific serum antibodies are used as an aid in the diagnosis and for monitoring the compliance with gluten free diet.
\end{abstract}

\section{STRESZCZENIE}

Opryszczkowate zapalenie skóry jest rzadką, przewlekłą, autoimmunologiczną chorobą pęcherzową, przebiegającą $\mathrm{z}$ nadwrażliwością na gluten i obecnością intensywnego świądu. Skórną manifestacją jest występowanie symetrycznych, polimorficznych zmian skórnych grupujących się w układzie opryszczkowatym w typowej lokalizacji. Schorzenie to jest specyficzną skórną manifestacją choroby trzewnej, $\mathrm{z}$ często utajoną enteropatią glutenową. Obie choroby charakteryzuje związek z tymi samymi antygenami zgodności tkankowej, obecnością krążących przeciwciał IgA przeciwko endomysium mięśni gładkich i transglutaminazom oraz kliniczna remisja pod wpływem diety bezglutenowej. Nieprzestrzeganie diety bezgutenowej predysponuje do rozwoju niektórych chorób nowotworowych, autoimmunologicznych i chorób tarczycy. Rozpoznanie opiera się na stwierdzeniu w badaniu immunofluorescencji bezpośredniej charakterystycznych złogów IgA w brodawkach skóry. Oznaczanie swoistych surowiczych przeciwciał wykorzystuje się pomocniczo $\mathrm{w}$ diagnostyce oraz do monitorowania przestrzegania diety.

Key words: celiac disease, dermatitis herpetiformis, gluten, autoimmune thyroiditis.

Słowa kluczowe:celiakia, opryszczkowate zapalenieskóry, gluten, autoimmunologiczne zapalenie tarczycy. 


\section{INTRODUCTION}

Dermatitis herpetiformis (DH; Duhring disease) is a chronic dermatosis with the presence of intense pruritus and characteristic polymorphic exanthemata found in typical locations. It is counted among subepidermal bullous diseases caused by autoimmunization to enzymes (transglutaminases), and it is often concomitant with latent gluten-sensitive enteropathy $[1,2]$.

\section{EPIDEMIOLOGY}

The disease is relatively rare, and occurs predominantly in the Caucasian race, sometimes locally in e.g. the state of Utah in the USA $(30 / 100,000)$ and Northern Europe [3]. It appears sporadically in the Yellow and Black races (Japan 10-34/150,000,000) [4], rarely in South America (eating habits; without gluten), and almost never among native inhabitants of Africa (low consumption of wheat), what is associated with lack of HLA DQ2. The DH incidence in Europe falls within the range of 11.4-39.2 per 100,000 [1]; it is most common in Finland - 75/100,000 [5, 6] and Sweden 19.6-39.2/100,000 inhabitants [7]. Men are more often affected (men to women ratio: $3: 2$ ), at all ages and most often between the age of 15 and 40; the disease usually starts between the age of 34 and $49[5,6,8]$. A 6-month-old infant was the youngest described case [9], whereas a 90-year-old individual was the oldest one to be diagnosed with the disease [10]. In adults over 40, DH occurs more often in women, in whom it starts earlier [1]. It is the most popular autoimmune bullous disease in children, and appears approximately at the age of 7 , with girls dominating. $\mathrm{DH}$ is more clearly more popular in children in Italy than in other countries [11], and less popular in Finland (about $4 \%$ of patients) [12]. A clear tendency for familiar occurrence is estimated at $2.4-6.5 \%[13,14]$. There ware six pairs of twins described: three pairs suffered from DH, in two pairs one twin had DH and the other one celiac disease $(\mathrm{CD})$, and in one pair one twin had DH and the other one was healthy, what proves common genetic background and the influence of environmental factors on both diseases [15]. About $5 \%$ of patients have siblings and $18 \%$ has relatives that suffer from DH [16]. In both diseases, HDL DQ2 and DQ8 are inherited, and the presence of both alleles in the patients is characterized by $100 \%$ sensitivity. Studies show that this is a recessive inheritance pattern [17].

\section{CLINICAL PICTURE}

Dermatitis herpetiformis manifests itself by symmetrical exanthemata forming garland-like patterns

\section{WPROWADZENIE}

Opryszczkowate zapalenie skóry (inaczej choroba Duhringa, morbus Duhring, dermatitis herpetiformis - DH) jest przewlekłą dermatozą przebiegającą z intensywnym świądem oraz charakterystycznymi polimorficznymi zmianami skórnymi występującymi w typowej lokalizacji. Zaliczana jest do podnaskórkowych chorób pęcherzowych $\mathrm{z}$ autoimmunizacji wobec enzymów (transglutaminaz). Zazwyczaj towarzyszy jej utajona jelitowa nadwrażliwość na gluten $[1,2]$.

\section{EPIDEMIOLOGIA}

Choroba występuje stosunkowo rzadko, przede wszystkim u osób rasy kaukaskiej, lokalnie częściej np. w stanie Utah w Stanach Zjednoczonych (30/ 100 000) i Europie Północnej [3]. U rasy żółtej i czarnej spotyka się ją sporadycznie (Japonia 10-34/ 150000 000) [4], rzadko w Ameryce Południowej (nawyki żywieniowe - bez glutenu) i wyjątkowo wśród rdzennych mieszkańców Afryki (niskie spożycie pszenicy), co się wiąże z niewystępowaniem HLA DQ2. Częstość występowania DH w Europie mieści się w granicach 11,4-39,2/100 000 [1], największa jest w Finlandii - 75/100 000 [5, 6] i Szwecji - 19,6-39,2/100 000 mieszkańców [7]. Choroba częściej dotyka mężczyzn (stosunek mężczyzn do kobiet - $3: 2$ ), może się pojawić w każdym wieku, najczęściej między 15. a 40. rokiem życia, średnio rozpoczyna się w wieku 34-49 lat [5, 6, 8]. Najmłodszy opisany chory to 6-miesięczne niemowlę [9], a najstarszy miał 90 lat $\mathrm{w}$ chwili postawienia diagnozy [10]. Wśród dorosłych poniżej 40. roku życia DH występuje częściej u kobiet, u których rozpoczyna się wcześniej [1]. Schorzenie to jest najczęstszą autoimmunologiczną chorobą pęcherzową dzieci, pojawia się ok. 7. roku życia, przeważnie u dziewczynek. U dzieci DH stwierdza się wyraźnie częściej we Włoszech niż w innych krajach [11], natomiast w Finlandii rzadziej (ok. 4\% chorych) [12]. Wyraźna tendencja do występowania rodzinnego jest oceniana na 2,4-6,5\% [13, 14]. Opisano sześć par bliźniąt, wśród których trzy pary chorowały na DH, w dwóch jedno z bliźniąt miało $\mathrm{DH}$, a drugie celiakię (celiac diseases - CD) oraz $\mathrm{w}$ jednej parze jeden bliźniak miał $\mathrm{DH}$, a drugi był zdrowy, co udowadnia wspólne tło genetyczne oraz wpływ czynników środowiskowych na obie choroby [15]. Około 5\% pacjentów ma rodzeństwo, a 18\% krewnych pierwszego stopnia cierpiących na DH [16]. W obu chorobach HLA DQ2 i DQ8 są dziedziczone, a obecność obu alleli u chorego charakteryzuje się prawie 100-procentową czułością. Wyniki badań wykazują, że jest to model dziedziczenia recesywnego [17]. 
in typical locations. The exanthemata are polymorphous, and the following may appear: erythematous spots, wheal responses, papulae, small blisters or blisters, erosions, crusts, and hypercoloured as well as discoloured spots (figs. 1, 2). In over $90 \%$ of patients, skin lesions are distributed on extensor surfaces; in about $2 / 3$ of patients, they are on the buttocks and knees, less often on shoulder blades, shoulder girdle and neck, stomach, groin, armpits, scalp, face, hands, and feet (fig. 3). Small, repeated scrapes can result in a Köbner phenomenon, which involves lesions in irritated locations (belts, underwear). Periorbital oedema may appear on eyelids [1, 18-21]. Exanthemata restricted to knees and elbows are called Cottini type. Duhring specified several types of the disease: erythematous, bullous, vesicular, pustular, and multiform - all of then can be concomitant [18]. Blisters are seldom visible; as a result of scratching, small erosions covered in crusts, excoriations, and then, hyperpigmentations appear fast. In milder cases, only hypercolourations and hyperpigmentations are visible [11, 18, 22]. Lichenous scutes may occur, whereas large blisters are rarely observed. Scars do not usually appear [1, 2, 18, 23].

Atypical clinical pictures include the following lesions: haemorrhagic petechiae on hands and feet [24], vasculitis-like lesions [25], palmar and plantar keratosis [26], chronic urticaria [27], and lesions imitating prurigo pigmentosa [28]. Erythematous lesions or intense pruritus were described as the only DH symptoms (fig. 4) [29], and exanthemata involving the face only [30]. Involvement of oral mucous membranes is extremely rare (1-10\% of patients) - erosions, small ulcers, or aphthae with accompanying sensation or dryness and burning in the oral cavity. Vesicular lesions may be found in the vermillion border $[1,31]$.

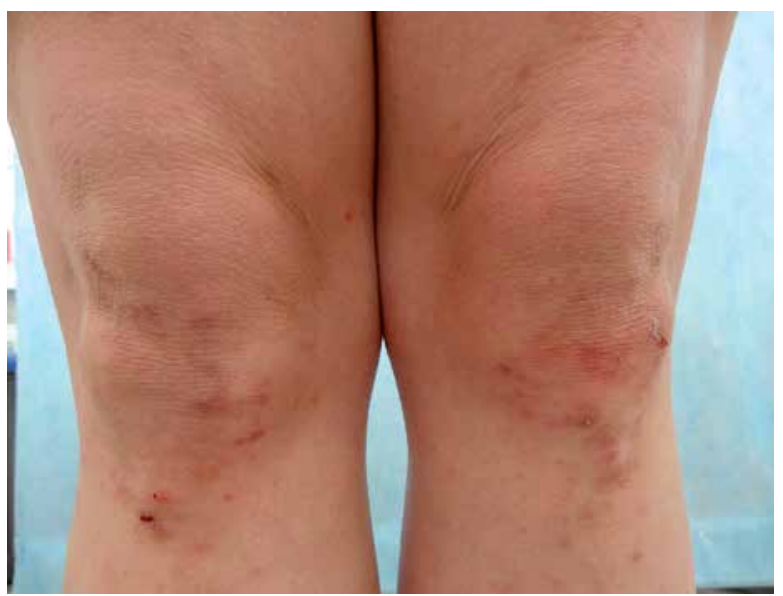

Figure I. Papules, erosions, hypo and hyperpimented spots in a typical location (knees)

Rycina I. Pojedyczne grudki, nadżerki, odbarwienia i przebarwienia w typowej lokalizacji (kolana)

\section{OBRAZ KLINICZNY}

Opryszczkowate zapalenie skóry objawia się jako symetryczne zmiany grupujące się w układzie opryszczkowatym (wianuszkowatym) w typowej lokalizacji. Osutka jest polimorficzna - występują plamy rumieniowe, bąble pokrzywkowe, grudki, małe pęcherzyki lub pęcherze, nadżerki, strupy, plamy o typie przebarwień i odbarwień (ryc. 1, 2). U ponad $90 \%$ chorych zmiany lokalizują się w okolicy wyprostnych części kończyn, u ok. 2/3 pacjentów na pośladkach i kolanach, rzadziej łopatkach, obręczy barkowej i karku, brzuchu, pachwinach, pachach, skórze owłosionej głowy i twarzy oraz rękach i stopach (ryc. 3). Drobne, powtarzające się otarcia są prawdopodobnie czynnikiem koebneryzującym, co jest przyczyną występowania zmian w miejscach narażonych na podrażnienie (paski od spodni, bielizna). Na powiekach może pojawić się obrzęk okołooczodołowy [1, 18-21]. Zmiany ograniczone do kolan i łokci nazywa się odmianą Cottiniego. Duhring wyróżnił kilka odmian choroby: rumieniową, pęcherzykową, pęcherzową, krostkową, grudkową i wielopostaciową, które mogą ze sobą współistnieć [18]. Pęcherze widoczne są rzadko, w wyniku drapania szybko pojawiają się drobne nadżerki pokryte strupkami, przeczosy, a następnie przebarwienia. W łagodniejszych przypadkach widoczne są tylko przebarwienia i odbarwienia [11, 18, 22]. Mogą występować zliszajcowaciałe tarczki, jednak duże pęcherze obserwowane są rzadko. $Z$ reguły nie występują blizny [1, 2, 18, 23].

Do nietypowych obrazów choroby należą zmiany typu wybroczyn krwotocznych na rękach i stopach [24], vasculitis-like [25], rogowca dłoni i podeszew [26], pokrzywki przewlekłej [27] i imitujące prurigo pigmentosa [28]. Opisano zmiany rumieniowe lub intensywny świąd jako jedyny objaw DH (ryc. 4) [29] oraz zmiany występujące tylko na twarzy [30]. Zajęcie błon śluzo-

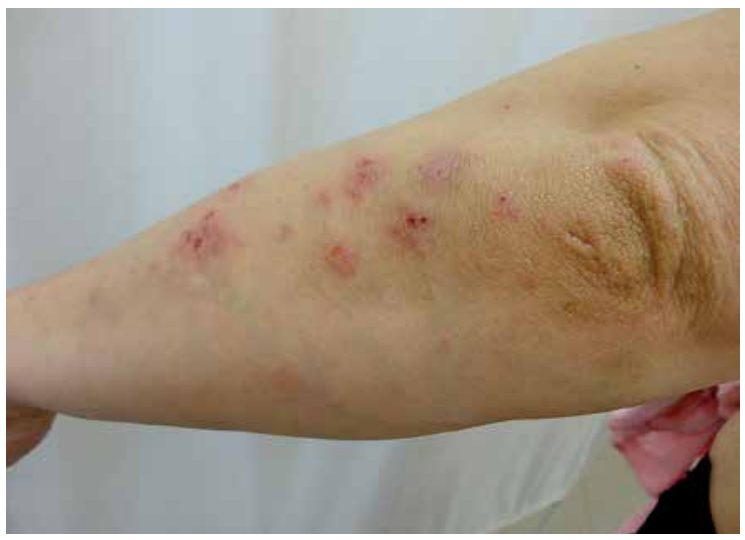

Figure 2. Polymorphic lesions - erythema, erosions covered by crusts, small scars and hyperpigmentations in a typical location (elbows and forearms)

Rycina 2. Polimorficzne zmiany rumieniowo-obrzękowe, nadżerki pokryte strupkami, drobne blizenki i przebarwienia w typowej lokalizacji (łokcie i przedramiona) 


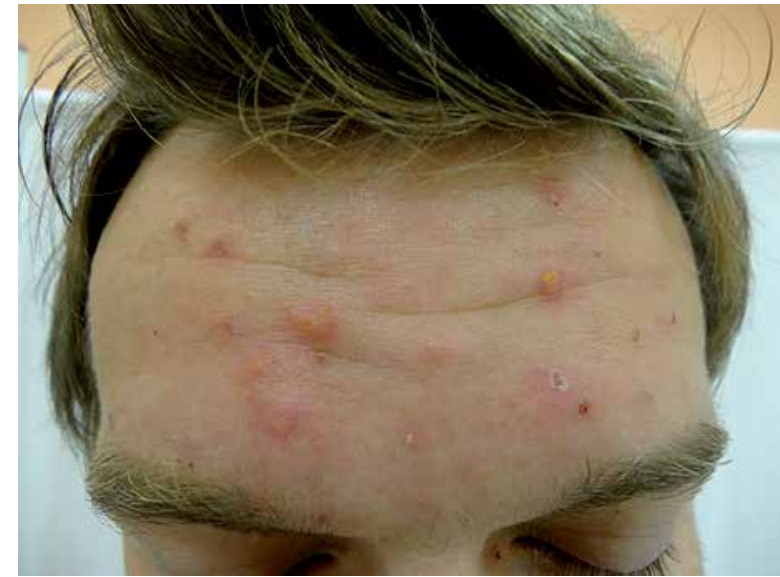

Figure 3. Blisters filled with serous fluid and erythematous lesions in a rare location (face)

Rycina 3. Pęcherzyki wypełnione surowiczą treścią na podłożu rumieniowym w rzadkiej lokalizacji (twarz)

Persistent pruritus is characteristic; less often patients experience burning, pricking, or stinging sensation of the skin that appears or intensifies 8-12 hours before appearance of new skin lesions, and then accompanies them. Particularly intense pruritus may considerably restrict everyday activities. Its intensification is individual and depends on the patient, observing gluten-free diet (GFD), its duration, and it gradually decreases when the patients start the diet. Persistent pruritus with periodic exanthemata indicates incomplete GFD or unconscious consumption of hidden gluten sources [1, 18-21]. Pruritus may persist despite the proper diet. About $1.7 \%$ of patients present a so-called refractory $\mathrm{DH}$, when in spite of long-term strict GFD, disappearance of intestinal lesions, and low titre or negativization of antibodies, patients present typical clinical symptoms and require symptomatic treatment. This form is different from analogues resistant $\mathrm{CD}$ form, in which despite the long-term GFD, intestinal lesions continue to be present [32].

Dermatitis herpetiformis is a life-long disease with periods of exacerbations and reduction. Intensification of symptoms is individual, independent of patient's age in which the disease was diagnosed, and in mild cases, periods of exanthema remission and recurrence that last several years are observed. Spontaneous DH remission (no skin lesions and symptoms in patients that do not that symptomatic drugs and do not use GFD for over 2 years) may occur in about $12 \%$ of patients, and its likelihood is associated with older age of the patient upon diagnosis [33]. In women, symptoms sometimes intensify before the period and improve when it starts [34]. The effects of pregnancy may be different in women some report that the course is milder during that time.

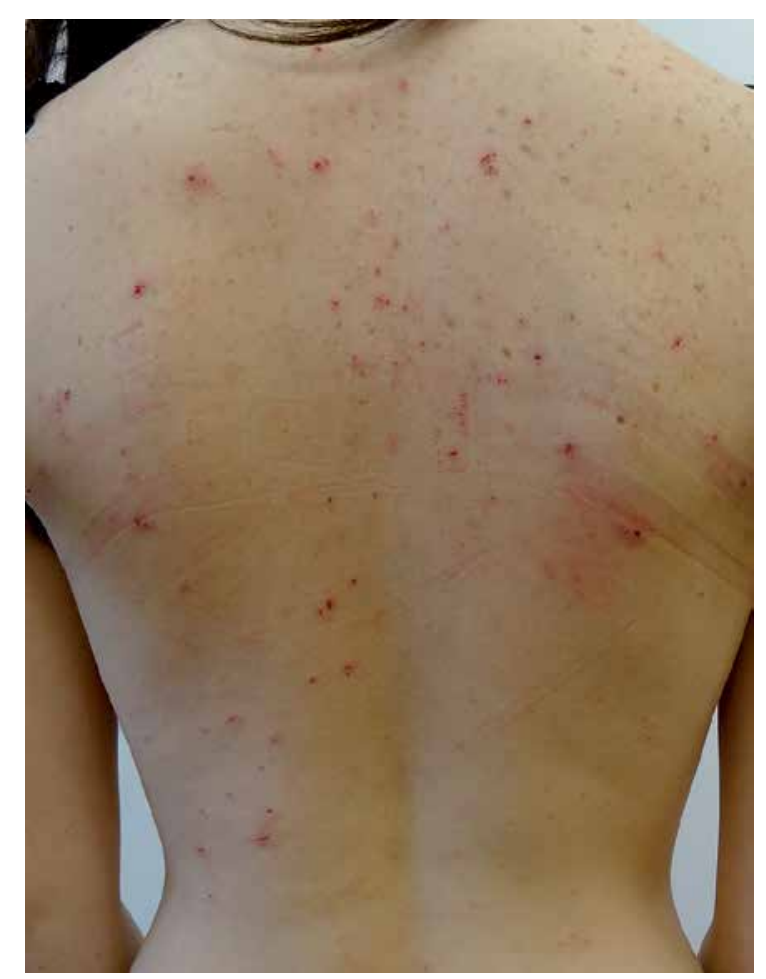

Figure 4. Diffuse, multiple excoriations as a symptom of severe pruritus

Rycina 4. Rozsiane, liczne przeczosy świadczące o nasilonym świądzie

wych jamy ustnej jest bardzo rzadkie (1-10\% chorych), w takich przypadkach zmiany mają postać nadżerek, drobnych owrzodzeń lub aft z uczuciem suchości i pieczenia w jamie ustnej. Można spotkać zmiany pęcherzykowe w obrębie czerwieni wargowej $[1,31]$.

Charakterystyczny jest uporczywy świąd, rzadziej uczucie palenia, kłucia lub pieczenia skóry pojawiające się lub nasilające 8-12 godzin przed wystąpieniem nowych zmian skórnych i towarzyszące tym zmianom. Bardzo intensywny świąd może znacznie utrudniać codzienne funkcjonowanie. Jego nasilenie jest indywidualne, zależy od pacjenta, stopnia przestrzegania diety bezglutenowej (gluten free diet - GFD) i czasu jej trwania, ustępuje powoli po jej włączeniu. Uporczywe utrzymywanie się świądu z występującymi okresowo zmianami świadczy o niepełnej GFD lub nieświadomym spożywaniu ukrytych źródeł glutenu [1, 18-21]. Świąd skóry może się utrzymywać pomimo prawidłowej diety. U ok. 1,7\% pacjentów występują objawy tzw. opornego DH (refractory DH), gdy pomimo wieloletniej, ścisłej GFD, ustąpienia zmian jelitowych, niskich mian lub negatywizacji przeciwciał pacjenci mają typowe objawy kliniczne i wymagają leczenia objawowego. Postać ta różni się od analogicznej opornej postaci CD, w której pomimo prawidłowej wieloletniej GFD obecne są nadal zmiany jelitowe [32].

Opryszczkowate zapalenie skóry jest chorobą na całe życie, z okresami zaostrzeń i złagodzenia obja- 
Furthermore, appearance of the first symptoms during pregnancy was described [1].

Papers regarding connections between $\mathrm{DH}$ and $\mathrm{CD}$ are somehow inconsistent with regard to classification; $\mathrm{DH}$ is described as: a skin disease concurrent with CD, skin manifestation of CD [35], separate disease entity including gluten-sensitivity, continual CD spectrum [23], undiagnosed [36] atypical CD, or a complication of untreated CD [37]. Currently, it is believed that $\mathrm{DH}$ is a specific skin expression of gluten-sensitive enteropathy (GSE) secondary to CD [38]. One may read about connection between $\mathrm{DH}$, $\mathrm{CD}$ and gluten ataxia since their common feature is gluten sensitivity [35].

General condition of patients if good and the majority of them do not have symptoms originating in the gastrointestinal track, symptoms related to poor absorption or malnutrition. Two-thirds or patients experience morphological lesions of the intestinal mucous membrane: total or partial villous atrophy, elongation of crypts, decrease in the number of villi/ crypts, increased lymphocyte mitotic index, presence of infiltrations from plasma cells, lymphocytes, mastocytes, eosinophils, and basophiles in the lamina propria [39]. GSE picture is confirmed in even $87 \%$ of patients according to American studies [20]. Gastrointestinal symptoms occur in $13-20 \%$ of patients; steatorrhea (loose, stinky, and glistering stools) appears most often periodically or continually, and less than $10 \%$ of patients have intestinal cramps, stomachache, bloating, or an increase in the abdominal circumference $[20,36]$. In $1 / 5-1 / 3$ of patients, the absorption disorders of the following are observed: D-xylose, iron, folic acid and vitamin $\mathrm{B}_{12}$ and also fats, lactose, glucose, calcium, and zinc; incidentally - anaemia due to iron insufficiency and osteopenia without an increased firm for bone fractures [1, 2, 40, 41]. Sixteen percent of children suffer from chronic diarrhoea, $10 \%$ from iron deficiency anaemia, exceptionally growth disorders, and only $5 \%$ of children that are on normal diet have normal mucosa of the small intestine [42]. About 5\% of CD-patients will develop DH symptoms within their lifetime [40].

\section{CONCOMITANT DISEASES}

In DH-patients, standardized mortality rate (SMR) is considerably higher than in general population (and it is higher in CD), and the SMR is significantly lower due to cardio-vascular reasons, what is probably influenced by strict GFD and lower consumption of unhealthy products, lower percentage of smokers and hypercholesterolemia as compared with the general population [43]. An increased risk of a malignant neoplasm, especially non-Hodgkin lymphoma (especially of the stomach and small intestine) is estimated wów. Nasilenie objawów jest indywidualne, nie zależy od wieku chorego, w którym ustalono rozpoznanie, a w łagodnych przypadkach obserwuje się okresy kilkuletnich remisji i nawrotów osutki. Samoistna remisja DH (brak zmian skórnych i objawów u pacjentów nieprzyjmujących leków i niestosujących GFD przez ponad 2 lata) może wystąpić u ok. 12\% pacjentów, a jej prawdopodobieństwo wiąże się z późniejszym wiekiem chorego w chwili rozpoznania [33]. U kobiet czasem obserwuje się zaostrzenie objawów przed miesiączką i poprawę wraz z jej wystąpieniem [34]. Wpływ ciąży może być różny u poszczególnych kobiet, część autorów stwierdza łagodniejszy przebieg podczas ciąży. Opisano również pojawienie się pierwszych objawów w ciąży [1].

W piśmiennictwie na temat powiązań $\mathrm{DH}$ i CD występuje pewna niespójność dotycząca klasyfikacji. Opryszczkowate zapalenie skóry jest opisywane jako: choroba skóry współtowarzysząca CD, skórna manifestacja CD [35], odrębna jednostka chorobowa z nadwrażliwością na gluten, ciągłe spektrum CD [23], niezdiagnozowane [36], atypowe CD lub powikłanie nieleczonej CD [37]. Aktualnie uważa się, że DH jest specyficzną skórną ekspresją enteropatii glutenowej (gluten-sensitive enteropathy - GSE) w przebiegu CD [38]. Można się spotkać z powiązaniem DH, CD i ataksji glutenowej, których cechą wspólną jest nadwrażliwość na gluten [35].

Stan ogólny chorych jest dobry i większość z nich nie ma dolegliwości ze strony przewodu pokarmowego, objawów złego wchłaniania i niedożywienia. U 2/3 pacjentów występują następujące zmiany morfologiczne błony śluzowej jelita: całkowity lub częściowy zanik kosmków jelitowych (total/severe or partial villous atrophy), wydłużenie krypt, zmniejszenie liczby kosmków lub krypt, podwyższony indeks mitotyczny limfocytów, obecność nacieków z komórek plazmatycznych, limfocytów, mastocytów i eozynofilów oraz bazofilów w blaszce właściwej [39]. W badaniach amerykańskich aż u $87 \%$ pacjentów stwierdza się obraz GSE [20]. Objawy żołądkowo-jelitowe stwierdza się u 13-20\% chorych, najczęściej jest to okresowo lub stale występująca biegunka tłuszczowa (luźne, cuchnące i połyskujące stolce), a u mniej niż 10\% skurcze jelit, bóle brzucha, wzdęcia, zwiększenie obwodu brzucha $[20,36]$. U 1/5-1/3 pacjentów obserwuje się zaburzenia wchłaniania D-ksylozy, żelaza, kwasu foliowego i witaminy $\mathrm{B}_{12}$ a także tłuszczów, laktozy, glukozy, wapnia i cynku, incydentalnie anemię z niedoboru żelaza oraz osteopenię bez zwiększonego ryzyka złamań kości [1, 2, 40,41]. Wśród dzieci 16\% ma przewlekłe biegunki, 10\% niedokrwistość z niedoboru żelaza, wyjątkowo zaburzenia wzrostu, a tylko $5 \%$ dzieci będących na normalnej diecie ma prawidłową błonę śluzową jelita cienkiego [42]. U ok. 5\% pacjentów z CD w ciągu całego życia wystąpią objawy DH [40]. 
at about $1 \%$ [44-47], although there exists data that do not confirm this type of risk as compared with the general population [41]. Higher SMR for lymphoproliferative growths occur only within the first five years from the moment when $\mathrm{DH}$ was diagnosed and GFD introduced, and the risk regards patients with regular diet since it is probably the inflammation of the small intestine mucosa that disturbs immunological reactivity caused by exposure to gluten $[43,44,46$, 48]. Perhaps there exists a common genetic-dependent immunological defect for $\mathrm{DH}$ and $\mathrm{CD}$ that predisposes to neoplastic transformation (connected to HLA B8/DR3). Female patients with DH have breast cancer less often than the general population [41, 45].

The connection of $\mathrm{DH}$ with autoimmune diseases may regard about $10 \%$ of patients, and disregard for GFD predisposes for their development. About 9.5\% of patients experience connective tissue diseases, and $5.2 \%$ - endocrinologic disorders [49]. The incidence of autoimmune thyroiditis ranges from $14 \%$ in the US to $4.3 \%$ (3.3\% with hypoactivity, and $1 \%$ with hyperactivity) in Finland $[49,50]$. Elevated levels of antithyroglobulin (anti-TG) and anti-thyroid peroxidase (anti-TPO) antibodies occur in 22-30\%, both in IgG and IgA class (48\% and $29 \%$, respectively), although thyroid diseases are diagnosed in about $5 \%$ of patients [51-53]. Abnormalities in thyroid hormones (mainly hypoactivity) are present in about $7 \%$ of $\mathrm{DH}-$ patients. Atrophy of the thyroid secondary to Hashimoto's thyroiditis (thyroid volume $<4.4 \mathrm{ml}$ ) may be found in $24 \%$ of patients ( $90 \%$ are women); however, Hashimoto's struma does not occur. Atrophic chronic lymphocytic thyroiditis (associated with HLA-B8 and HLA-DRw3) and nodous form (HLA-DR5) are forms that accompany $\mathrm{DH}$ [51]. In about $5 \%$ of patients with autoimmune thyroiditis, anti-tTg antibodies in IgA class are confirmed [54].

Type I diabetes affects about $2 / 3 \%$ of DH-patients, i.e. it is over three times more common than in the general population of children, and less common than in CD-patients (5.4\%). In the immunological process, destruction of cells producing insulin probably starts together with damage of cells in the intestinal mucosa. Diabetes precedes DH symptoms and diagnosis with a number of years according to the patient's age when it is diagnosed. Diet - diabetic and GFD - is more challenging to be followed. Among the first-degree relatives of patients, type I diabetes is also more common [55].

Autoimmune diseases concomitant with $\mathrm{DH}$ include: systemic lupus erythematosus (1.3\%), Sjögren's syndrome $(1.0 \%)$, sarcoidosis $(1.3 \%)$, vitiligo $(1.3 \%)$, and malignant anaemia. The majority of diseases start before DH diagnosis, what suggests that GFD protects from the risk of developing the disease [49].

\section{CHOROBY WSPÓŁISTNIEJACE}

U pacjentów z DH standaryzowany wskaźnik umieralności (standardized mortality rate - SMR) jest znacząco niższy niż w populacji ogólnej (a w CD jest wyższy), chorzy ci mają też istotnie niższy SMR z przyczyn sercowo-naczyniowych. Wpływa na to prawdopodobnie ścisłe stosowanie GFD, mniejsze spożycie niezdrowych produktów, mniejszy odsetek palaczy i hipercholesterolemii w porównaniu z populacją ogólną [43]. Zwiększone ryzyko nowotworu złośliwego, zwłaszcza chłoniaka typu non-Hodgkin (zwłaszcza żołądka i jelita cienkiego) ocenia się na ok. $1 \%$ [44-47], choć istnieją dane, które nie potwierdzają tego ryzyka w porównaniu z populacją ogólną [41]. Wyższy SMR dla rozrostów limfoproliferacyjnych występuje tylko w czasie pierwszych 5 lat od rozpoznania DH i wprowadzenia GFD, a ryzyko dotyczy chorych stosujących normalną dietę, gdyż prawdopodobnie stan zapalny śluzówki jelita cienkiego zaburza odczynowość immunologiczną wywołaną przez ekspozycję na gluten $[43,44,46,48]$. Być może istnieje wspólny dla DH i CD, genetycznie zależny defekt immunologiczny predysponujący do przemiany nowotworowej (związany z układem HLA B8/DR3). Kobiety z DH rzadziej chorują na raka piersi niż w populacji ogólnej [41, 45].

Związek DH z chorobami autoimmunologicznymi może dotyczyć ok. $10 \%$ pacjentów, a nieprzestrzeganie GFD predysponuje do ich rozwoju. U ok. 9,5\% pacjentów występują choroby tkanki łącznej, a u 5,2\% zaburzenia endokrynologiczne [49]. Częstość występowania autoimmunologicznego zapalenia tarczycy waha się od 14\% w Stanach Zjednoczonych do 4,3\% (3,3\% z niedoczynnością i $1 \%$ z nadczynnością) w Finlandii $[49,50]$. Podwyższone poziomy przeciwciał przeciwko tyreoglobulinie (anty-TG) i przeciwko peroksydazie tarczycowej (anty-TPO) występują u 22-30\% zarówno w klasie IgG i IgA (odpowiednio u $48 \%$ i $29 \%$ ), chociaż chorobę tarczycy rozpoznaje się u ok. $5 \%$ chorych [51-53]. Nieprawidłowości w zakresie hormonów tarczycy (głównie niedoczynność) obecne są średnio u ok. 7\% chorych na DH. Zanik gruczołu tarczowego w przebiegu choroby Hashimoto (objętość tarczycy $<4,4 \mathrm{ml}$ ) można spotkać u $24 \%$ pacjentów (90\% to kobiety), nie występuje natomiast postać wola guzowatego Hashimoto. Postacią towarzyszącą DH jest zanikowe przewlekłe limfocytarne zapalenie tarczycy (związane z HLA-B8 i HLA-DRw3) i postać guzowata (HLA-DR5) [51]. U ok. 5\% pacjentów z autoimmunologicznym zapaleniem tarczycy stwierdza się przeciwciała przeciwko tTg w klasie IgA [54].

Cukrzyca typu 1 występuje u ok. 2,3\% pacjentów z DH, czyli ponad 3 razy częściej niż w populacji ogólnej dzieci, ale rzadziej niż u pacjentów z CD $(5,4 \%)$. Zniszczenie $\mathrm{w}$ procesie immunologicznym komórek produkujących insulinę rozpoczyna się 
Chronic gastritis (associated with Helicobacter pylori infection) is rare, but its incidence increases systematically. Inflammatory lesions of the body suggest an autoimmune factor. Atrophic gastritis secondary to DH increases the risk of stomach cancer, and thus, patients who do not follow GFD should have biopsies from the duodenum, body and fund us taken [56]. Achlorhydria and hypochlorhydria occur in $50 \%$ of patients, parietal cell autoantibodies (PCAs) in 14\%, whereas anti-islet cell antibodies do not occur [52]. Abnormalities of the tooth enamel include horizontal grooves, small holes and hyperpigmentations [57].

Incidence of psoriasis in DH-patients is estimated at $1.6 \%$, similarly to the general population [49]. Till 2007, 11 cases of leucoderma were described that mostly preceded DH symptoms. Injuries may lead to the Köbner phenomenon as a result of scratching, and consequently, activate leucodermal lesions [58].

Isolated cryofibrinogenaemia (precipitates composed of fibrinogen, fibrin, fibronectin, and factor VIII develop in patient's serum at $4^{\circ} \mathrm{C}$ ) is significantly more frequent ( $49 \%$ of patients) $-60 \%$ of patients are on regular diet, without dapsone (DPS), and $60 \%$ are only on GFD. Cryoprecipitates are not confirmed in patients treated with GFD and DPS, what probably indicates protective effects of DPS [59].

Body mass measured according to BMI (body mass index) in DH-patients does not differ from the general population, whereas obesity (BMI $>30 \mathrm{~kg} / \mathrm{m}^{2}$ ) is confirmed in $7 \%$ of patients, and is slightly less common than in the general population (9\%) [41].

\section{IODINE AND THE DERMATITIS HERPETIFORMIS COURSE}

Consumption of iodides exacerbates the disease. A potassium iodide patch test is positive in patients during the active $\mathrm{DH}$, and negative during remission as well as in patients following GFD and/or using DPS [60]. Iodine is contained in some foods (iodised and sea salt, sea fish and seafood, eggs, peas, cherries, and oranges) and air at the seaside. In patients, in whom GFD and/or DPS fully control DH symptoms, iodine does not usually trigger pruritus or exanthemata, and therefore, iodine-deficient diet is recommended only in some patients that react to iodine [1].

\section{DRUGS AND THE DERMATITIS HERPETIFORMIS COURSE}

Drugs that intensify DH symptoms include: nonsteroidal anti-inflammatory drugs (indomethacin, acetylsalicylic acid, diclofenac, flurbiprofen, and ibuprofen), oncological drugs (doxorubicin, vincristine, cyclophosphamide), psychiatric drugs (lithium, prawdopodobnie równolegle z uszkodzeniem komórek śluzówki jelita. Cukrzyca o wiele lat wyprzedza objawy i rozpoznanie DH, zgodnie z wiekiem chorego, w którym się je rozpoznaje. Dieta - cukrzycowa i GFD - jest trudniejsza do przestrzegania. Wśród krewnych pierwszego stopnia chorych cukrzyca typu 1 również występuje częściej [55].

Choroby autoimmunologiczne współistniejące z DH to: toczeń rumieniowaty układowy $(1,3 \%)$, zespół Sjögrena $(1,0 \%)$, sarkoidoza $(1,3 \%)$, bielactwo nabyte $(1,3 \%)$ i niedokrwistość złośliwa. Większość chorób rozpoczyna się przed rozpoznaniem $\mathrm{DH}$, co sugeruje, że GFD chroni przed zachorowaniem [49].

Przewlekłe zapalenie błony śluzowej żołądka jest rzadkie (związane z infekcją Helicobacter pylori), ale systematycznie wzrasta częstość jego występowania. Zmiany zapalne trzonu sugerują czynnik autoimmunologiczny. Zanikowe zapalenie śluzówki żołądka w DH zwiększa ryzyko wystąpienia raka żołądka, dlatego u pacjentów niestosujących GFD rekomenduje się pobranie biopsji z dwunastnicy, trzonu i dna żołądka [56]. Achlorhydria i hipochlorhydria występują u 50\% chorych, przeciwciała przeciwko komórkom okładzinowym żołądka (parietal cell autoantibody - PCA) u 14\%, natomiast nie występują przeciwciała przeciwko komórkom wysp trzustki [52]. Nieprawidłowości szkliwa zębowego to rowki o układzie horyzontalnym, dołki oraz przebarwienia [57].

Częstość występowania łuszczycy u pacjentów z DH ocenia się na 1,6\%, podobnie jak w populacji ogólnej [49]. Do 2007 r. opisano 11 przypadków bielactwa, które w większości poprzedzało objawy DH. Urazy w wyniku drapania wydają się czynnikiem koebneryzującym, który prowadzi do aktywacji zmian bielaczych [58].

Istotnie częściej (u 49\% chorych) występuje izolowana kriofibrynogenemia (tworzenie się w osoczu pacjenta $\mathrm{w}$ temperaturze $4^{\circ} \mathrm{C}$ precypitatów złożonych z fibrynogenu, fibryny, fibronektyny i czynnika VIII) w porównaniu z populacją ogólną (0-7\%), w tym u $60 \%$ będących na normalnej diecie, bez dapsonu (DPS) oraz u 40\% na samej GFD. Nie stwierdza się krioprecypitatów u pacjentów leczonych GFD i DPS, co prawdopodobnie świadczy o ochronnym działaniu DPS [59].

Masa ciała mierzona jako wskaźnik masy ciała (body mass index - BMI) u chorych na $\mathrm{DH}$ nie różni się $\mathrm{w}$ porównaniu z populacją ogólną, a otyłość (BMI $>30 \mathrm{~kg} / \mathrm{m}^{2}$ ) stwierdzana jest u $7 \%$ pacjentów, nieco rzadziej niż w populacji ogólnej (9\%) [41].

\section{WPŁYW JODU NA PRZEBIEG OPRYSZCZKOWATEGO ZAPALENIA SKÓRY}

Spożycie jodków wywołuje zaostrzenie choroby. Test płatkowy (patch test) z jodkiem potasu jest dodatni tylko u chorych w aktywnym okresie $\mathrm{DH}$, a ujemny 
amitryptylina), oral contraceptives, levothyroxine, and propafenone [61]. Amiodarone contains 6-8 mg of free iodine in 1 tablet, and may significantly trigger symptoms among the patients that react to this element, especially given the fact that this drug has a long half-life period (up to 100 days). DH provocations during a treatment with infliximab (probably a promotion of autoimmune response in individuals predisposed by TNF- $\alpha$ inhibitors) and interferon- $\alpha$ as well as ribavirin (chronic hepatitis $C$ ) were described $[62,63]$. One should also remember about medical procedures associated with administration of iodine contrast media.

\section{CONFLICT OF INTEREST}

The authors declare no conflict of interest. w okresie remisji i stosowania GFD i/lub DPS [60]. Jod zawarty jest w niektórych pokarmach (sól jodowana i morska, ryby morskie i owoce morza, jaja, groch, wiśnie i pomarańcze) oraz $\mathrm{w}$ powietrzu w okolicach nadmorskich. U chorych, u których GFD i/lub DPS kontrolują w pełni objawy $\mathrm{DH}$, jod nie wywołuje $\mathrm{z}$ reguły świądu lub osutki, dlatego tylko u części pacjentów reagujących na jod zaleca się dietę ubogojodową [1].

\section{WPŁYW LEKÓW NA PRZEBIEG OPRYSZCZKOWATEGO ZAPALENIA SKÓRY}

Wśród leków nasilających objawy DH wymienia się: niesteroidowe leki przeciwzapalne (indometacyna, kwas acetylosalicylowy, diklofenak, flurbiprofen i ibuprofen), onkologiczne (doksorubicyna, winkrystyna, cyklofosfamid), psychiatryczne (lit, amitryptylina), doustne leki antykoncepcyjne, lewotyroksynę i propafenon [61]. Amiodaron zawiera 6-8 mg wolnego jodu $\mathrm{w}$ jednej tabletce i może wywoływać objawy u chorych reagujących na ten pierwiastek, zwłaszcza że jest lekiem o długim okresie półtrwania (do 100 dni). Opisywano wystąpienie DH w trakcie leczenia infliksymabem (prawdopodobnie promowanie reakcji autoimmunologicznej u osób predysponowanych przez inhibitory TNF- $\alpha$ ) oraz interferonem $\alpha$ i rybawiryną (przewlekłego wirusowego zapalenia wątroby typu C) $[62,63]$. Należy też pamiętać o procedurach medycznych związanych z podawaniem jodowych środków kontrastowych.

\section{KONFLIKT INTERESÓW}

Autorzy nie zgłaszają konfliktu interesów.

\section{References \\ Piśmiennictwo}

1. Dmochowski M.: Autoimmunizacyjne dermatozy pęcherzowe. UM Poznań, 2006, 281-311.

2. Żebrowska A., Waszczykowska E., Kowalewski C., Woźniak K., Olszewska M., Placek W.: Diagnostyka i postępowanie terapeutyczne w opryszczkowatym zapaleniu skóry (w chorobie Duhringa) - konsensus Polskiego Towarzystwa Dermatologicznego. Prz Dermatol 2016, 103, 95-101.

3. Smith J., Tulloch J., Meyer L., Zone J.: The incidence and prevalence of dermatitis herpetiformis in Utah. Arch Derm 1992, 128, 1608-1610.

4. Shibahara M., Nanko H., Shimizu M., Kanda N., Kubo M., Ikeda M.: Dermatitis herpetiformis in Japan: an update. Derm 2002, 204, 37-42.

5. Reunala T., Lokki J.: Dermatitis herpetiformis in Finland. Acta Derm Venereol 1978, 58, 505-510.

6. Salmi T., Hervonen K., Kautiainen H., Collin P., Reunala T.: Prevalence and incidence of dermatitis herpetiformis: a 40-year prospective study from Finland. Br J Derm 2011, 165, 354-359.

7. Mobacken H., Kastrup W., Nilsson L.A.: Incidence and prevalence of dermatitis herpetiformis in Sweden. Acta Derm Venereol 1984, 64, 400-404.

8. Bolotin D., Petronic-Rosic V.: Dermatitis herpetiformis. Part I. Epidemiology, pathogenesis, and clinical presentation. J Am Acad Dermatol 2011, 64, 1017-1024.

9. Safai B., Rappaport I., Matsuoka L., Sogn D., Haines K., Lewin M.: Childhood dermatitis herpetiformis. Review of the new aspects and report of a case. J Am Acad Dermatol 1981, 4, 435-441.

10. Christensen O., Hindsen M., Svensson A.: Natural history of dermatitis herpetiformis in southern Sweden. Dermatologica $1986,173,271-277$.

11. Antiga E., Verdelli A., Calabrò A., Fabbri P., Caproni M.: Clinical and immunopathological features of 159 patients with dermatitis herpetiformis: an Italian experience. G Ital Dermatol Venereol 2013, 148, 163-169. 
12. Hervonen K., Salmi T.T., Kurppa K., Kaukinen K., Collin P., Reunala T.: Dermatitis herpetiformis in children: a long-term follow-up study. Br J Derm 2014, 171, 1242-1243.

13. Reunala T.: Incidence of familial dermatitis herpetiformis. Br J Dermatol 1996, 134, 394-398.

14. Meyer L., Zone J.: Familial incidence of dermatitis herpetiformis. J Am Acad Dermatol 1987, 17, $643-647$.

15. Hervonen K., Karell K., Holopainen P., Collin P., Partanen J., Reunala T.: Concordance of dermatitis herpetiformis and celiac disease in monozygous twins. J Invest Dermatol 2000, 115, 990-993.

16. Hervonen K., Hakanen M., Kaukinen K., Collin P., Reunala T.: First-degree relatives are frequently affected in coeliac disease and dermatitis herpetiformis. Scand J Gastroenterol 2002, 37, 51-55.

17. Greenberg D., Hodge S., Rotter J.: Evidence for recessive and against dominant inheritance at the HLA-linked locus in coeliac disease. Am J Hum Genet 1982, 34, 263-277.

18. Duhring L.: Dermatitis herpetiformis. JAMA 1884, 3, 225-229.

19. Antiga E., Caproni M.: The diagnosis and treatment of dermatitis herpetiformis. Clin Cosmet Investig Dermatol 2015, 8, 257265.

20. Alonso-Llamazares J., Gibson L., Rogers R.: Clinical, pathologic, and immunopathologic features of dermatitis herpetiformis: review of the Mayo Clinic experience. Int J Dermatol 2007, 46, 910-919.

21. Calonje J., Brenn T., Lazar A., McKee P.: Mckee's Pathology of the Skin. Elsevier 2012, 144-147.

22. Fry L.: Dermatitis herpetiformis: problems, progress and prospects. Eur J Dermatol 2002, 12, 523-531.

23. Reunala T.: Dermatitis herpetiformis. Clin Dermatol 2001, 19, 728-736.

24. Hofmann S., Nashan D., Bruckner-Tuderman L.: Petechiae on the fingertips as presenting symptom of dermatitis herpetiformis Duhring. J Eur Acad Dermatol Venereol 2009, 23, 732-733.

25. Naylor E., Atwater A., Selim M., Hall R., Puri P.: Leukocytoclastic vasculitis as the presenting feature of dermatitis herpetiformis. Arch Dermatol 2011, 147, 1313-1316.

26. Ohshima Y., Tamada Y., Matsumoto Y., Hashimoto T.: Dermatitis herpetiormis Duhring with palmoplantar keratosis. Br J Dermatol 2003, 149, 1300-1302

27. Powell G.R., Bruckner A., Weston W.: Dermatitis herpetiformis presenting as chronic urticarial. Pediatr Dermatol 2004, 21, 564-567.

28. Saito M., Böer A., Ishiko A., Nishikawa T.: Atypical dermatitis herpetiformis: a Japanese case that presented with initial lesions mimicking prurigo pigmentosa. Clin Exp Dermatol 2006, 31, 290-291.

29. Junkins-Hopkins J.: Dermatitis herpetiformis: pearls and pitfalls in diagnosis and management. J Am Acad Dermatol 2010, 63, 526-528.

30. Cinats A., Parsons L., Haber R.: Facial involvement in dermatitis herpetiformis: a case report and review of the literature. J Cutan Med Surg 2019, 23, 35-37.

31. Romańska-Gocka K.: Opryszczkowate zapalenie skóry: etiopatogeneza, klinika i leczenie. Przegl Dermatol 1999, 86, $499-509$.

32. Hervonen K., Salmi T., Ilus T., Paasikivi K., Vornanen M., Laurila K.: Dermatitis herpetiformis refractory to gluten-free dietary treatment. Acta Derm Venereol 2016, 96, 82-86.

33. Paek S., Steinberg S., Katz S.: Remission in dermatitis herpetiformis: a cohort study. Arch Dermatol 2011, 147, $301-305$.

34. Leitao E., Bernhard J.: Perimenstrual nonvesicular dermatitis herpetiformis. J Am Acad Dermatol 1990, $22,331-334$.

35. Herrero-González J.: Guía clínica de diagnóstico y tratamiento de la dermatitis herpetiforme. Actas Dermosifiliogr 2010, 101, 820-826.

36. Zone J.: Skin Manifestations of Celiac Disease. NIH Consensus Development Conference on Celiac Disease. Bethesda, Maryland 2004, 73-75.

37. Lovett W.: Dermatitis herpetiformis and a gluten-free diet. Am Fam Physician 2003, 67, 470-471.

38. Kárpáti S.: Dermatitis herpetiformis: close to unravelling a disease. J Dermatol Sci 2004, 34, 83-90.

39. Fry L., Seah P., Harper P., Hoffbrand A., McMinn R.: The small intestine in dermatitis herpetiformis. J Clin Pathol 1974, 27, 817-824.

40. Kotze L.: Dermatitis herpetiformis, the celiac disease of the skin! Arch Gastroenetrol 2013, 50, $231-235$.

41. Lewis N., Logan R., Hubbard R., West J.: No increase in risk of fracture, malignancy or mortality in dermatitis herpetiformis: a cohort study. Aliment Pharmacol Ther 2008, 27, 1140-1147.

42. Hervonen K., Salmi T., Kurppa K., Kaukinen K., Collin P., Reunala T.: Dermatitis herpetiformis in children: a long-term follow-up study. Br J Dermatol 2014, 171, 1242-1243.

43. Hervonen K., Alakoski A., Salmi T., Helakorpi S., Kautiainen H., Kaukinen K.: Reduced mortality in dermatitis herpetiformis: a population-based study of 476 patients. Br J Dermatology 2012, 167, 1331-1337.

44. Tucker W., Leonard J., Fry L.: Increased risk of lymphoma in dermatitis herpetiformis. J R Soc Med 1983, 76, 95-97.

45. Grainge M., West J., Solaymani-Dodaran M., Card T., Logan R.: The long-term risk of malignancy following a diagnosis of coeliac disease or dermatitis herpetiformis: a cohort study. Aliment Pharmacol Ther 2012, 35, 730-739.

46. Reunala T., Salmi T.T., Hervonen K.: Dermatitis herpetiformis: pathognomonic transglutaminase IgA deposits in the skin and excellent prognosis on a gluten-free diet. Acta Derm Venereol 2015, 95, 917-922.

47. Hervonen K., Vornanen M., Kautiainen H., Collin P., Reunala T.: Lymphoma in patients with dermatitis herpetiformis and their first-degree relatives. Brit J Dermatology 2005, 152, 82-86.

48. Lewis H., Renaula T., Garioch J., Leonard J., Fry J., Collin P.: Protective effect of gluten-free diet against development of lymphoma in dermatitis herpetiformis. Br J Dermatol 1996, 135, 363-7.

49. Reunala T., Collin P.: Diseases associated with dermatitis herpetiformis. Br J Dermatol 1997, 136, 315-318.

50. Cunningham M., Zone J.: Thyroid abnormalities in dermatitis herpetiformis: prevalence of clinical thyroid disease and thyroid autoantibodies. Ann Intern Med 1985, 102, 194-196.

51. Zettinig G., Weissel M., Flores J., Dudczak R., Vogelsang H.: Dermatitis herpetiformis is associated with atrophic but not with goitrous variant of Hashimoto's thyroiditis. Eur J Clin Invest 2000, 30, 53-57. 
52. Gawkrodger D., Blackwell J., Gilmour H., Rifkind E., Heading R., Barnetson R.: Dermatitis herpetiformis: diagnosis, diet and demography. Gut 1984, 25, 151-157.

53. Weetman A., Burrin J., Mackay D., Leonard J., Griffiths C., Fry L.: The prevalence of thyroid autoantibodies in dermatitis herpetiformis. Br J Dermatol 1988, 118, 377-383.

54. Kamalanathan S., Sahoo J., Selviambigapathy J., Vivekanandan M.: Serological marker of dermatitis herpetiformis in hypothyroidism due to Hashimoto's thyroiditis. Indian J Endocrinol Metab 2015, 19, 855-856.

55. Hervonen K., Viljamaa M., Collin P., Knip M., Reunala T.: The occurrence of type 1 diabetes in patients with dermatitis herpetiformis and their first-degree relatives. Br J Dermatol 2004, 150, 136-138.

56. Alakoski A., Salmi T., Hervonen K., Kautiainen H., Salo M., Kaukinen K.: Chronic gastritis in dermatitis herpetiformis: a controlled study. Clin Dev Immunol 2012, 7476, 640630.

57. Katsambas A., Lotti T., Dessinioti C., D'Erme A.: European Handbook of Dermatological Treatments. Springer 2015, $191-195$.

58. Karabudak O., Dogan B., Yildirim S., Harmanyeri Y., Anadolu-Brasie R.: Dermatitis herpetiformis and vitiligo. J Chin Med Assoc 2007, 70, 504-506.

59. Bognár P., Görög A., Kárpáti S.: High prevalence of cryofibrinogenaemia in dermatitis herpetiformis. J Eur Acad Dermatol Venereol 2016, 30, 517-518.

60. Haffenden G., Blenkinsopp W., Ring N., Wojnarowska F., Fry L.: The potassium iodide patch test in the dermatitis herpetiformis in relation to treatment with a gluten-free diet and dapsone. Br J Dermatol 1980, 103, 313-317.

61. Tousignant J., Lafontaine N., Rochette L., Rozenfarb E.: Dermatitis herpetiformis induced by nonsteroidal anti-inflammatory drugs. Int J Dermatol 1994, 33, 199-200.

62. Marakli S., Uzun S., Ozbek S., Tuncer I.: Dermatitis herpetiformis in a patient receiving infliximab for ankylosing spondylitis. Eur J Dermatol 2008, 18, 88-89.

63. Borghi-Scoazec G., Merle P., Scoazec J., Claudy A., Trepo C.: Onset of dermatitis herpetiformis after treatment by interferon and ribavirin for chronic hepatitis C. J Hepatol 2004, 40, 871-872.

Received: 16.01 .2019

Accepted: 19.10 .2019

Otrzymano: $16.01 .2019 \mathrm{r}$.

Zaakceptowano: 19.10 .2019 r.

How to cite this article

Rybak-d'Obyrn J.I., Placek W.J.: Clinical picture of dermatitis herpetiformis. Dermatol Rev/Przegl Dermatol 2019 , $106,615-624$. DOI: https://doi.org/10.5114/dr.2019.92734 